\title{
Preface
}

My father fought a hard war. He fought Hitler, prosecuting the war with a violence that proved uncontainable. I don't know how to solve that, but without men like my father the war would not have been won!

—Derek Jarman, The Last of England (1987)

I began to think about the arguments presented in this book in 2003 when the beginning of war in Iraq made it hard not to see war everywhere. I found that the books I read, the records I listened to, and the films and shows I watched all seemed to be about war even when they had evidently little to do with war. In ways both necessary and helplessly trivial, I felt that I saw war everywhere and that seeing war was maybe what interpretation was for. But why? What made looking for evidence of war where it apparently wasn't seem like a necessity? Why was it that war seemed to touch objects and ideas so distant from it? Was this creeping significance a matter of my imagination - maybe even my guilt — or was it rather evidence of something larger, a shift in how one thinks during a conflict that was imagined as open-ended and exceptional? How did a war, which was only barely about itself, manage to make everything else about war, too? With these questions in mind, I began with my colleague Alan Tansman to prepare graduate and undergraduate courses on war and representation. We paired texts that addressed particular wars with contemporary novels, poems, or films that seemed to have little or nothing to do with their wars, that is, with texts that held their wars "at a distance."1 How did representations work differently as they drifted across the porous border between texts that treated war and its consequences directly and those that addressed them obliquely or not at all? The Iliad is about war and so is All Quiet on the Western Front (1929). Although they don't address their wars directly, there is little doubt that Ford Madox Ford's The Good Soldier (1915), Sam Peckinpah's The Wild Bunch (1969), and Erich Auerbach's Mimesis (1946) are also about war. But 
what about examples where the relation is more tenuous but maybe no less real: what about Singin' in the Rain (1952) or The Theory of the Novel (1920) or Salem's Lot (1975)? Both Laurence Olivier's and Kenneth Branagh's Henry V (1944 and 1989, respectively) are of course about their wars, but what about David Lean's Brief Encounter (1945) or his Great Expectations (1946)? War seems in some of these cases to be exactly where it is not; although neither allegorized nor referred to, war feels like an invisible and obscure but no less animating spirit in these and other wartime examples.

In addition to reminding us of its own presence, weight, and pathos, war can thus reveal what's always strained about aboutness, a quality that can and perhaps needs to mean several things at once. To be about is, according to the Oxford English Dictionary, to be "all over or around," "at large," "without any definite purpose," "on the move," "to one side, aside, away," "in circumference," "around the outside," "in every direction," "approximately," "more or less," "with regard to," and, finally, "to have as a subject matter, to be concerned with." As a number of critics have recently suggested, war can highlight the essentially impacted nature of aboutness. Alex Woloch argues that George Orwell's war writing "is (oddly) 'about' intentionality, 'about' about-ness. It doesn't merely seek to transmit this intention but to dramatize it." Marina MacKay writes that "modernist writing produced between 1914 and 1918 stretched the concept of 'aboutness' almost to its breaking point in its approach to the war that saw its publication." ${ }^{3}$ Mary Favret suggests that, at least since the late eighteenth century, war has become as much a shared, qualifying, and ambient idea about the world as a quantifiable state of affairs: "War becomes an object of knowledge, a universalizing abstraction; indeed, in wartime it threatens to become all you know." Kate McLoughlin writes that, in many of the best cases, war texts succeed because they fail "to write about war, writing instead about the difficulties of its representation. ${ }^{\prime 5}$ In each of these cases, these critics take the scope, the inclusiveness, and the violence of war as a challenge to representation, reference, and aboutness; because modern wars tend to colonize everything else at the level of the experience and the concept, because they are traumatic, because they undermine the difference between civilian and soldier, private and public, inside and outside, it is hard from within the ambit of a war to say that anything is simply and directly about anything else. Aboutness, like metaphor, relies on difference, which is itself one of modern war's less obvious casualties.

Beginning with the fraught relation between war and representation, I turned to a few films made in Britain during World War II that to me seem to call particular attention to problems that war posed for aesthetic 
representation: The Life and Death of Colonel Blimp (1943), Henry V (1944), and Brief Encounter (1945). What did it mean practically to shoot and to edit a film in the context of total mobilization? In what ways can the form and the content of cinema specifically respond to the concept of total war? Was everything that fell within the assertively capacious frame of total war somehow about war? How did World War II's avowed status as a war for national survival put pressure on the cinematic treatment of everyday life and national character? How, as the war progressed, did filmmakers deal with anxieties that came not only with war but also with the anticipated approach of war's end, with the idea of life lived after the transformative social dislocations of war? What would viewers who were living or who had lived through years of blackout, bombing, rationing, and dislocation have seen, heard, and felt when they bought a ticket, entered a darkened cinema, and saw a film more or less about war? More to the point, how might these particular films help us to see a more general relation between total war and cinematic representation and thus to understand the limits of aesthetic representation when faced with organized violence?

There are, of course, many ways to approach these questions. One could write a more or less comprehensive history of filmmaking during the war years and look at how the nuts and bolts of war administration intersected with the film industry; one could work to prepare an atlas or glossary of films made during the war in order to isolate themes, motifs, and ideas that correspond with this or that phase of the war as it unfolded: the Phoney War, the Battle of Britain, the Battle of the Atlantic, the opening of the Eastern Front, and so on; or one could proceed biographically, looking at the ways that directors, actors, cinematographers, producers, and others brought individual experiences to their various attempts to represent and to understand World War II. These approaches are variously represented in a number of important books on the British cinema, including Anthony Aldgate and Jeffrey Richards's Britain Can Take It: British Cinema and the Second World War (1994), James Chapman's The British at War: Cinema, State and Propaganda, 1939-1945 (1998), Charles Drazin's The Finest Years: British Cinema of the 1940s (2007), Antonia Lant's Blackout: Reinventing Women for Wartime British Cinema (1991), S. P. MacKenzie's British War Films: 1939-1945 (2006), Robert Murphy's British Cinema and the Second World War (2000), and Neil Rattigan's This Is England: British Film and the People's War, 1939-1945 (2001).

While I draw often on these writers and others, I employ a more speculative method. A reader of an early draft suggested that what follows is not film studies but rather film writing. Though meant as criticism, the 
distinction is probably a good one. I try to write on, through, and about these films not from within the terms of one or another field but rather as aesthetic objects whose significance, complexity, and pathos exceed their status as evidence for or against the value of this or that methodology. In this my work comes closer (in intent if not quality) to recent examples of historically charged aesthetic writing about war such as Alexander Nemerov's Icons of Grief: Val Lewton's Home Front Pictures (2005), T. J. Clark's The Sight of Death: An Experiment in Art Writing (2006), Leo Mellor's Reading the Ruins: Modernism, Bombsites and British Culture (2011), and Sarah Cole's At the Violet Hour: Modernism and Violence in England and Ireland (2012). In each of these cases, novels, paintings, and films are taken not only as evidence within a historical record but also as a problematic kind of history, as forms in which the tension, pressure, or paradox of history as a process is at least partially embodied or encoded. Consequently, I also look back to a long and idiosyncratic strain of historical thinking differently represented by figures such as Marc Bloch, Norbert Elias, Simone Weil, Walter Benjamin, and Johann Huizinga, all of whom are writers I look to and write about in what follows. To my mind, these figures share a sense that art and culture can, at their best, not only embody or represent a moment in time but also disrupt assumptions about the present's relation to the past and undo or at least reveal tricks we play on ourselves in order to forget what we owe that past. As they bring the past into rough contact with the present, art and culture lead, for better or worse, into the future. It is no coincidence that Bloch, Elias, Weil, Benjamin, and Huizinga wrote about war during and - if they were lucky - after war, a fact that forces us to confront ways in which, as Marina MacKay writes in an essay on the wartime origins of Ian Watt's The Rise of the Novel, "critical writing is subject to the same historical and biographical contingencies as those traditionally admitted with respect to other forms of writing."

I am most interested here in how the experience of war's violence came together with political ambivalences that were particular to the British scene before and during the war to put a productive pressure on film style and specifically cinematic modes of representation. Such an object of study indeed makes a strong, close, and sometimes intuitive kind of reading necessary. Put differently, the enormity of the violence of World War II, its avowed conceptual status as a total war, and the complex emotional and ethical responses that the war elicited produced a situation in which connotations that unfurl across the levels of film form, film content, and film style demand interpretation in the strongest sense; as Roland Barthes writes, "to interpret a text is not to give it a (more or less justified, more or less free) 
meaning, but on the contrary to appreciate what plural constitutes it." ${ }^{\prime 7}$ Because I want to look to the films themselves in order to ask what war-weary filmmakers and audiences might have seen, thought, and felt when they made or watched films that were more and less about war during a time of war, I take for granted the possibility that these films possess a formal and aesthetic complexity - a semantic plurality — that exceeds good and necessary empirical questions about institutional history, influence, and intention. I have, in other words, to think about aboutness as an occasion not for declaration but, crucially, for connotation, association, and suggestion.

If we cannot say for sure what the past thought about itself, we can at least identify some of those thoughts' overlapping and sometimes incommensurate conditions of possibility; maybe that's what history or, perhaps, historicity is: a shifting conceptual horizon against or through which we try to see and understand each other and ourselves. It is a field of hopes, beliefs, good and bad ideas, practices, dispositions, and habits that makes other beliefs, ideas, and practices possible but almost never necessary. I want both to understand how cinema became an especially appropriate and enormously popular medium through which to think about the nature of violence during World War II and to understand how it resulted from and contributed to history understood as that field of conceptual possibility. How did resources specific to the cinematic medium-cutting, casting, color, sound design - allow filmmakers and audiences to engage with the difficulties of thinking about total war ${ }^{8}$ The different but related temporalitiesthe specific historicity - of war and cinema come together to make these questions especially vital. While popular memory tends to treat World War II as a single period, people living through it experienced particular years, seasons, months, and weeks as periods distinct in and of themselves. The early days of the Phoney War were felt as different in kind from the Battle of Britain, which was itself felt as different in kind from everything that followed. We can see this accelerated process of auto-periodization at work in journals and diaries. For instance, Hugh Trevor-Roper was able in 1942 to look back to 1940 with real nostalgia, which is to say to look at that year as a time really different from his present; he writes about reading his journal from that other year: "I read through again the chronicle of that memorable year in our history, and was astonished at the serene, effortless confidence with which we accepted, and reacted to, the most colossal disasters. Had we paused to think, we would have seen that we had been defeated, and that the value of further resistance was questionable; but this intellectual process never occurred to us, and we survived." ${ }^{\prime 9}$

This sense of wartime as an internally fractured set of distinct periods 
had a particular significance for filmmakers, particularly those who were committed in one way or another to cinema as a form of democratic propaganda. Because, in other words, it takes a long time to make a film, the specific problems that wartime films try to address (guilt over appeasement, anticipation of invasion, the experience of the Blitz, wariness about the nature of Anglo-American relations, worry about social life after wartime, etc.) were often already out-of-date by the time the films in fact appeared. "The feature film," writes Nicholas Reeves, "is too unwieldy a weapon to deploy in these kind of propaganda campaigns and, almost without exception, films that were designed to play a part in such particular, time-specific campaigns failed to meet their original objectives. ${ }^{10}$ We need, in that case, to see that a film made in 1942 and released in 1943 would have been reacting to problems that were maybe most alive in 1941, a fact that, given the compressed and internally differentiated nature of Britain's wartime, made each film into an especially volatile mix of residual, dominant, and emergent ideas about a war that was changing all the time. ${ }^{11}$

What's conceptually difficult and even paradoxical about World War II thus takes several forms in War Pictures. It was, for instance, said again and again both in films and in other contexts that, because World War II was a total war, the British had to suspend values that had seemed to define the national character in order to protect those values from destruction at the hands of Hitler and the Nazis. In order to save civilization, civilization had to be sacrificed; values had to be suspended in order to protect those same values; immoral methods had to be adopted so as to overcome immorality. Following the proverbial logic of "it takes a thief to catch a thief," the paradoxical and dispiriting idea that "it takes a fascist to fight a fascist" was everywhere during the war years, finding fraught expression in journals, diaries, political speeches, opinions about the war captured by Mass-Observation, as well as in novels, poems, documentaries, and feature films. ${ }^{12}$ For reasons that I'll describe in what follows, I take this dilemmathat it takes a fascist to fight a fascist - to be both necessary to the British experience of total war and a structuring formal impetus behind some of the best British films of those years. In this regard, War Pictures is in conversation with a number of recent books about the culture and society of the British home front, works that attempt both to address the broad ambivalences and ambiguities of World War II and look to ways in which the specific fact or fantasy of total war put pressure on local experiences of class, gender, national identity, and empire; I'm thinking here of Adam Piette's Imagination at War: British Fiction and Poetry 1939-1945 (1995), Karen Schneider's Loving Arms: British Women Writing the Second World 
War (1997), Mark Wollaeger's Modernism, Media, and Propaganda: British Narrative from 1900 to 1945 (2006), Lyndsey Stonebridge's The Writing of Anxiety: Imagining wartime in Mid-Century British Culture (2007), Patrick Deer's Culture in Camouflage (2009), Kristine A. Miller's British Literature of the Blitz: Fighting the People's War (2009), Marina Mackay's Modernism and World War II (2010), Susan R. Grayzel's At Home and Under Fire: Air Raids and Culture in Britain from the Great War to the Blitz (2012), Gill Plain's Literature of the 1940s: War, Postwar and "Peace" (2013), and Paul Saint-Amour's Tense Future: Modernism, Total War, Encyclopedic Form (2015).

In addition to thinking through some political and strategic paradoxes immanent to the British experience of total war, I'll also argue that the films on which I focus engage with an even more difficult wartime idea. Where from a certain view one can imagine that particular wars are responsible for particular periods of conflict and violence - that wars cause violence - the films I discuss entertain, largely at the level of style, the sobering possibility that an essential human tendency toward violence and aggression might in fact stand as a more general cause of this or that war: this is instead to imagine that violence — original, human, intransigent — causes war. In this way, these films echo and anticipate arguments about the precedence of violence and aggression found in Hobbes and de Maistre, Freud and Lacan, Walter Burkert's Homo Necans: The Anthropology of Ancient Greek Sacrifcial Ritual and Myth (1983) and Lawrence Keeley's War Before Civilization: The Myth of the Peaceful Savage (1996). ${ }^{13}$ This idea, that human aggression might precede and thus exceed even the totalizing damage of total war, is one that these films approach delicately, obliquely, and formally. The notion that wars are in some sense natural and inevitable - and thus that no war could end all or any wars - is a difficult, dispiriting one to make in the midst of a costly, draining campaign. Part of the aesthetic brilliance of these films comes from their willingness to make - at the level of cinematic technique and film style - so unhappy but so important an argument about war and its violence. 



\section{War Pictures}


